\title{
Measuring Neuroticism in Nepali: Reliability and Validity of the Neuroticism Subscale of the Eysenck Personality Questionnaire
}

\author{
Manandhar K, ${ }^{1,2}$ Risal A, ${ }^{1,2}$ Linde M, ${ }^{2,3}$ Koju R, ${ }^{1}$ Steiner TJ, ${ }^{2,4}$ Holen $\mathrm{A}^{2,5}$
}

${ }^{1}$ Dhulikhel Hospital, Kathmandu University Hospital, Kathmandu University School of Medical Sciences, Dhulikhel, Kavre, Nepal

${ }^{2}$ Department of Neuroscience, Norwegian University of Science and Technology, Trondheim, Norway

${ }^{3}$ Norwegian Advisory Unit on Headaches, St. Olavs University Hospital, Trondheim, Norway

${ }^{4}$ Division of Brain Sciences, Imperial College London, London, UK

${ }^{5}$ Pain Unit, St. Olavs University Hospital,

Trondheim, Norway

\section{Corresponding Author}

Kedar Manandhar

Department of Community Medicine

Dhulikhel Hospital, Kathmandu University School of Medical Sciences,

Dhulikhel, Kavre, Nepal

E-mail: manandhark2@gmail.com

\section{Citation}

Manandhar K, Risal A, Linde M, Koju R, Steiner TJ, Holen A. Measuring Neuroticism in Nepali: Reliability and Validity of the Neuroticism Subscale of the Eysenck Personality Questionnaire . Kathmandu Univ Med J 2015;50(2):156-61.

\section{ABSTRACT}

\section{Background}

The Neuroticism subscale of the Eysenck Personality Questionnaire Revised Short Form (12 items) (EPQRS-N) has proven to be a reliable and valid measure in multiple languages.

\section{Objective}

To develop a single-factor Nepali-language version of the EPQRS-N for use in the adult population of Nepal.

\section{Method}

The original English version of EPQRS-N was translated into Nepali using a forwardbackward translation protocol. The first set of translated items was modified after testing by factor analysis with principal component extraction in an outpatient sample. Items with low factor correlations or poor semantic consistencies were reworded to fit the gist of the original items in a Nepali cultural context; the revised version was then tested in a representative random sample from the general population. Again, the same statistical procedures were applied.

\section{Results}

The first trial gave three factors. Based on the factor distribution of the items or their semantic quality, five were reworded. In the second trial, a two-factor solution emerged; the second factor had only one item with high correlation, which also had modest correlation with the first factor. Accordingly, a forced one-factor solution was chosen. This gave an internal consistency (Cronbach's alpha) of 0.80 , with item-tofactor correlations from 0.40 to 0.73 , and item-to-sum correlations from 0.31 to 0.61 .

\section{Conclusion}

The final Nepali version of EPQRS-N achieved satisfactory internal consistency. The item distribution coincided with the original English version, providing acceptable construct validity. It is psychometrically adequate for use in capturing the personality trait of neuroticism, and has broad applicability to the adult population of Nepal because of the diversity of the participant samples in which it was developed.

\section{KEY WORDS}

Eysenck personality questionnaire, global campaign against headache, item translation, Nepal, neuroticism, personality traits, trans-cultural psychiatry 


\section{INTRODUCTION}

Trait theory is today the most prevalent scientific description of personality; personality traits are often defined as enduring patterns of thoughts, feelings and actions. ${ }^{1}$ Hans Eysenck claimed that there were three "super traits" capturing individual differences: extraversion, neuroticism and psychoticism. ${ }^{2}$ Later research brought forward a fivefactor model, displacing psychoticism and adding openness to experience, agreeableness and conscientiousness. ${ }^{1}$ Neuroticism has consistently been recognized as one of the main traits of personality. It represents emotional instability and reactivity; higher neuroticism scores display a propensity for anxiety, depression, shyness and/ or low self-esteem in contrast to individuals who are low on neuroticism; they tend to be emotionally stable and secure. ${ }^{3}$

Neuroticism is not a symptom per se, even though many studies have demonstrated higher levels of neuroticism to be consistently associated with psychiatric problems, ${ }^{4-6}$ and psychiatric diagnoses, e.g., depression, anxiety and personality disorders. ${ }^{6}$

Neuroticism is captured by personality inventories such as the Revised Eysenck Personality Questionnaire (EPQR-S) published in 1985 for use among adults ${ }^{7}$; it consists of four subscales, one of which covered neuroticism. In this paper, we focus solely on the psychometric development of a scale in Nepali capturing neuroticism. In line with similar studies in other countries, ${ }^{8-10}$ this scale will be referred to as the Eysenck Personality Questionnaire Revised Short Form - Neuroticism (EPQRS-N).

EPQRS-N is of special interest because of its inclination towards psychopathology. ${ }^{3}$ Moreover, it is short and easy to use in hospitals as well as in the general population. The English version of the scale includes some items with metaphorical expressions; they tend to be difficult to handle in cross-cultural translations. Even so, the scale has been replicable across cultures and countries. ${ }^{11}$ Asian language versions of EPQRS-N exist in Hindi, Japanese and Urdu. ${ }^{8,9,12}$ So far, no attempts at developing a Nepali version have been made.

\section{Aim of study}

Our purpose was to develop a Nepali-language version of EPQRS-N. For the construct validity, we required a singlefactor item distribution, like that of the original English version, so that the concept of neuroticism of the original version would be reproduced in the final Nepali version. We set predetermined statistical limits of acceptability: we required high item-correlations $(>0.30)$ with the main factor and low correlations with any other; moreover, every item should have a correlation of $>0.30$ with the total sum of the items. For internal consistency, we required a Cronbach's alpha of $>0.60 .^{13}$

\section{METHODS}

\section{Ethics}

This study was a part of a larger research project on the major disorders of the brain in Nepal, ${ }^{14,15}$ which had been approved by the Nepal Health Research Council (NHRC), the Institutional Review Committee of Kathmandu University School of Medical Sciences, Dhulikhel Hospital (IRC-KUSMS), and the Central Regional Committee for Health and Research Ethics in Norway. Informed consent was obtained from the participants in accordance with the requirements of the review boards in Nepal and Norway. Every participant gave his or her informed consent to participation in the study, indicating this either by signature or fingerprint.

\section{Participants - two samples}

To provide a broad base for assessing reliability and construct validity, we recruited two relevant but rather different samples. The first was a convenience sample of adult outpatients ( $\mathrm{N}=101$; male: 58 [57.4\%]; female: 43 [42.6\%]) attending the psychiatry, orthopaedic or surgery outpatient departments of Dhulikhel Hospital during June, 2012. The second was a representative sample from the general adult population of Nepal ( $N=2,100$; male: 861 [41\%]; female: 1,239 [59\%]) selected countrywide by stratified random sampling during May, 2013. Full details of this sampling procedure have been published elsewhere. ${ }^{15}$

\section{Instrument}

EPQRS-N consists of twelve items with dichotomous response options: 'No' scored 0 and 'Yes' scored 1 . The potential scoring range is $0-12$. Higher summed scores reflect higher levels of neuroticism.

\section{Translation and statistical analyses}

The original English-language version of EPQRS-N was given a literal translation into Nepali using a forward-backward translation method. ${ }^{16}$

After testing the first version in the outpatient sample, we assessed the items for semantic inconsistencies and ambiguities in the context of Nepali culture. Also, we performed statistical analyses (see below) to find items with a poor fit in relation to the main factor. Incongruous items were reworded. After these item adjustments, a second item set was tested in the second sample.

For construct validity, in seeking a one-factor solution, we applied factor analysis with principal component extraction and varimax rotation to check the number of principal components or factors. We used Cronbach's alpha coefficient to measure internal consistency, and also, the item-to-sum correlations were performed to check inconsistency of any item of the scale with the main factor. Analyses were carried out using the Statistical Package for Social Science software (IBM SPSS Statistics 21, USA). 


\section{RESULTS}

\section{First trial - outpatient sample}

From this trial, using the literal translation of original English version of EPQRS-N, three factors emerged. In the third column of Table 1, the correlations of each item are presented in relation to these three factors (F1, F2 and F3). Since the items were distributed on three factors, construct validity was not achieved and internal consistency was not calculated.

In the factor analysis, items 2, 5, 6, 7, 8, 9, 10, 11 and 12 were highly correlated with F1; these nine items had lower correlations with the other two factors. The remaining three items 1, 3 and 4, were distributed with high correlations on F2 and/or F3: item 1 had high correlations with F1 (0.53) and F3 (0.43); item 3 had low correlation with F1 (0.29) but high with F2 (0.74) and item 4 was distributed on all three factors (F1: 0.36; F2: 0.52; F3: 0.20. Accordingly, we reworded these three items in order to get closer to the one-factor solution. In addition, we modified items 6 and 12 because of semantic inconsistencies and ambiguities. Below, we describe the rewording in more detail.

\section{Items modified after statistical explorations}

Item 1, "Does your mood often go up and down?" correlated with two factors. We modified it to "Do you have an unstable mood?"

Item 3, "Are you an irritable person?" correlated poorly with F1 and better with F2. We changed it to "Are you an ill-tempered person?"

Table 1. Semantic and statistical item development of neuroticism subscale (EPQRS-N) in Nepali with correlations from factor analyses in the first and second trials

\begin{tabular}{|c|c|c|c|c|c|}
\hline \multirow[t]{2}{*}{ Item number } & \multirow[t]{2}{*}{ Text of items } & \multicolumn{3}{|c|}{$\begin{array}{l}\text { First trial }(\mathrm{N}=\mathbf{1 0 1}) \\
\text { Correlations with three factors }\end{array}$} & \multirow{2}{*}{$\begin{array}{l}\text { Second trial }(\mathrm{N}=\mathbf{2}, \mathbf{1 0 0}) \\
\text { Correlations with forced } \\
\text { one-factor solution }\end{array}$} \\
\hline & & F1 & F2 & F3 & \\
\hline 1 & $\begin{array}{l}\text { Does your mood often go up and down? } \\
\text { a. Ke tapai ko man tala mathi bairahanchha? } \\
\text { b. Ke tapai ko man asthir hunchha?* }\end{array}$ & 0.53 & -0.05 & 0.43 & 0.48 \\
\hline 2 & $\begin{array}{l}\text { Do you ever feel 'just miserable' for no reason? } \\
\text { a. Kunai karan bina tapai kahile dukhi hunu bhayako chha? }\end{array}$ & 0.62 & $-0,33$ & 0.32 & 0.54 \\
\hline 3 & $\begin{array}{l}\text { Are you an irritable person? } \\
\text { a. Ke tapaai chirchiraune baikti ho? } \\
\text { b. Tapai jhrkane Khal ko baikti ho?* }\end{array}$ & 0.2 & 0.74 & -0.01 & 0.40 \\
\hline 4 & $\begin{array}{l}\text { Are your feelings easily hurt? } \\
\text { a. Tapin ko man chaidai dhukhchha? } \\
\text { b. Ke Tapai ko bhavana ma turaitai chot pardachha?* }\end{array}$ & 0.36 & 0.52 & 0.20 & 0.57 \\
\hline 5 & $\begin{array}{l}\text { Do you often feel fed up? } \\
\text { a. Ke tapain praya nirasha bhayara basnu hunchha? }\end{array}$ & 0.69 & 0.28 & -0.27 & 0.71 \\
\hline 6 & $\begin{array}{l}\text { Would you call yourself a nervous person? } \\
\text { a. Ke tapain hotoshahit mahasus garne baikti ho? } \\
\text { b. Ke tapain aphulai atine manish thanu huncha?** }\end{array}$ & 0.68 & 0.01 & 0.33 & 0.64 \\
\hline 7 & $\begin{array}{l}\text { Are you a worrier? } \\
\text { a. Ke tapain chintit hunuhunch? }\end{array}$ & 0.72 & -0.18 & -0.05 & 0.73 \\
\hline 8 & $\begin{array}{l}\text { Would you call yourself tense or highly strung? } \\
\text { a. Tapin aphulain tanabgarsta wa atisable mahasus garnu- } \\
\text { hunchha? }\end{array}$ & 0.68 & 0.13 & -0.26 & 0.55 \\
\hline 9 & $\begin{array}{l}\text { Do you worry too long after embarrassing experiences? } \\
\text { a. Ke tapain kunai lajaspad ghatna ghataipachhi, lamo } \\
\text { samaya sama taiskai bare chinta gari rahanu huncha? }\end{array}$ & 0.49 & 0.05 & -0.62 & 0.47 \\
\hline 10 & $\begin{array}{l}\text { Do you suffer from nerves? } \\
\text { a. Ke tapain afno chinta bata dukhi hunuhunchha? }\end{array}$ & 0.72 & -0.32 & -0.19 & 0.64 \\
\hline 11 & $\begin{array}{l}\text { Do you often feel lonely? } \\
\text { a. Ke praya aphulai Yeklo mahasus garnu hunchha? }\end{array}$ & 0.68 & -0.07 & 0.06 & 0.55 \\
\hline 12 & $\begin{array}{l}\text { Are you often troubled about feeling of guilt? } \\
\text { a. Ke tapain aphulai le gareko kamdekhi paschtap garnu } \\
\text { hunchha? } \\
\text { b. Ke tapain praya aphai le gareko kam ya bhaneko kura } \\
\text { dekhi hinta boudha garnuhuncha?** }\end{array}$ & 0.60 & 0.16 & 0.16 & 0.41 \\
\hline Cronbach's alp & ta for internal consistency & & - & & 0.80 \\
\hline Range of item- & o-factor(s) correlations & & - & & $0.40-0.73$ \\
\hline Range of item- & o-sum correlations & & - & & $0.31-0.61$ \\
\hline
\end{tabular}


Item 4, "Are your feelings easily hurt?" For an appropriate literal meaning of 'feelings' in item 4, we had used the Nepali term 'maan' (mind), but it was distributed on all three factors in the initial round. We used instead the Nepali term 'bhavana' (emotion): "Are you easily hurt emotionally?"

\section{Items modified because of semantic inconsistencies and ambiguities}

Although we achieved satisfactory correlations for items 6 and 12, terms used in item 6 ('hatoshahit': discouraged) and item 12 ('paschatap': guilt) belong more to literature than to day-to-day use by the general population. For this reason, they were assessed as inconsistent and ambiguous to many, in particular to those who were illiterate. Accordingly, these two items were rephrased as 'attine' (worried) and 'hinatabodh' (feeling inferior) respectively.

\section{Second trial - general population}

In the revised version, tested in the general population sample, the number of factors was reduced from three to two. Eleven of the 12 items correlated highly (range 0.410.73) with F1 (main factor); only item 3 correlated more highly with F2. We reran the factor analysis with a forced one-factor solution by using an option within the factoranalysis command in SPSS: only one factor is permitted to appear; the last column of Table 1 shows the correlations that emerged. With this approach, Cronbach's alpha for internal consistency was 0.80 , the range of correlations with $\mathrm{F} 1$ was $0.40-0.73$ (item 3 being lowest), and item-tosum correlations were between 0.31 and 0.61 . The onefactor solution produced an explained variance of $32 \%$.

\section{DISCUSSION}

In two steps, we arrived at a final Nepali version of EPQRS-N with an internal consistency (Cronbach's alpha) that was in the range usually characterized as good and well above our predetermined goal for this property. ${ }^{13}$ With regard to the construct validity, all items in the final one-factor solution obtained correlations above our goal, indicating that the 12 items as currently worded form a unified concept of neuroticism coinciding well with the original English scale. The one item (Item 3) in Nepali that correlated better with a second factor in the second trial nonetheless comfortably exceeded, in the forced one-factor solution, our correlation requirement with the main factor. This indicates that although the item has overlapping features between two factors, in the forced one-factor approach it had an acceptable correlation, sufficient to achieve construct validity.

Unavoidably, problems appear when translating expressions, metaphors and everyday vernacular language into another language with rather different semantic structures and cultural settings. ${ }^{8,17}$ The correlation of Item 3 ('Are you an irritable person?') posed difficulties also in the translation into Hindi, ${ }^{8}$ in a neighbouring country, India, in which similar sociocultural issues arise. The particular problem related to this item may thus be of a cultural kind.

In a study comparing its psychometric properties in four English-speaking countries (England, Canada, USA and Australia), EPQRS-N achieved alpha coefficients in the range $0.78-0.87 .{ }^{18}$ Similar studies in non-English speaking European countries achieved coefficients in the range 0.72 0.84..$^{10,17,19}$ The alpha coefficient for the Nepali version was within the range those of the English-speaking countries and non-English speaking countries, slightly higher than those from the Asian countries, ${ }^{8,9}$ their range was 0.74 0.77 . This suggests that the Nepali version is comparable in psychometric strength to English and non-English language versions.

\section{Strengths and limitations}

The methodological strength of this study is that it was carried out in a stepwise manner using two different participant samples. The first trial recruited a small convenience sample of hospital outpatients, with, probably, a higher level of psychopathology ${ }^{20}$; it therefore brought out a diversity of psychopathological concepts. This guided our rephrasing of the items for the second trial in a large representative sample of adults from the general population of Nepal. Involving two diverse samples increased the chances of developing a Nepali version of EPQRS-N with broad application, to both hospital populations and the general population. In particular, the wide representativeness of the second sample was a major asset in securing this.

For logistic reasons, a test-retest trial was not carried out. This is a limitation of the study since, if successful, it would have strengthened the psychometric properties of the scale. Personality traits are supposed to be quite stable over time. ${ }^{3}$ Psychiatric symptoms, different from personality traits, are versatile states of mind. Test-retest intervals for symptom measures should therefore be brief, perhaps a few days, while the test-retest interval for enduring personality traits should be considerably longer, three months or more. It is for this reason that we were unable to conduct the test-retest study, since we could not return to the participants in the second sample.

A final limitation of the study is that we have not so far attempted a validation against well-trained psychiatrists' clinical confirmation. Accordingly, the sensitivity and specificity of the Nepali version of EPQRS-N await investigation.

\section{CONCLUSION}

The final Nepali version of EPQRS-N achieved good internal consistency and acceptable construct validity with a onefactor solution. It is psychometrically adequate for use in capturing the personality trait of neuroticism in the adult population of Nepal. 


\section{ACKNOWLEDGEMENTS}

This project was funded by grants from Samarbeidsorganet, the Liaison Committee between the Central Norway Regional Health Authority and the Norwegian University of Science and Technology (NTNU). It was conducted

\section{REFERENCES}

1. Costa PT, McCare RR. Four ways five factors are basic. Pers Individ Dif. 1992;13(6):349-56.

2. Eysenck HJ. Biological dimensions of personality. Hand book of personality: Theory and research, (pp 244-276)New York: Guilford Press. 1990.

3. Caspi A, Roberts BW, Shiner RL. Personality development: stability and change. Annu Rev Psychol. 2005;56:453-84.

4. Williamson RJ, Neale BM, Sterne A, Prince M, Sham P. The value of four mental health self-report scales in predicting interview-based mood and anxiety disorder diagnoses in sibling pairs. Twin research and human genetics : the official journal of the International Society for Twin Studies. 2005;8(2):101-7.

5. Rockliff HE, Lightman SL, Rhidian E, Buchanan H, Gordon U, Vedhara K. A systematic review of psychosocial factors associated with emotional adjustment in in vitro fertilization patients. Hum Reprod Update. 2014;20(4):594-613.

6. Volgsten H, Ekselius L, Poromaa IS, Svanberg AS. Personality traits associated with depressive and anxiety disorders in infertile women and men undergoing in vitro fertilization treatment. Acta Obstet Gynecol Scand. 2010;89(1):27-34.

7. Eyesnck SBG, Eysenck HJ, Barrett P. A revised version of the psychoticism scale Pers Individ Dif. 1985 6(1):21-9.

8. Tiwari T, Singh AL, Singh IL. The short-form revised Eysenck personality questionnaire: A Hindi edition (EPQRS-H). Industrial psychiatry journal. 2009;18(1):27-31.

9. Robert L. Validation of the neuroticism subscales using a Japanese sample. Social Behavior and Personality 1995;23(2):131-6.

10. Alexopoulos DS. Psychometric properties of Eysenck Personality Questionnaire- Revised (EPQ-R) Short Scale in Greece. Pers Individ Dif. 2004;37:1205 - 20. within the Global Campaign against Headache, led by the nongovernmental organization Lifting The Burden in official relations with the World Health Organization, and with the support of Dhulikhel Hospital, Kathmandu University Hospital, Dhulikhel, Kavre, Nepal.

11. Barrett PT, Petrides KV, Eysenck SBG, Eysenck HJ. The Eysenck Personality Questionnaire] an examination of the factorial similarity of $\mathrm{P}, \mathrm{E}, \mathrm{N}$, and L across 23 countries. Personality and Individual Diferences. 1998;25:805-19.

12. Lewis CA, Musharraf S. The short form Eysenck Personality Questionnaire-Revised (EPQR-S) and the revised abbreviated Eysenck Personality Questionnaire (EPQR-A): Urdu translations. J Pak Med Assoc. 2014;64(2):225-6.

13. Nunally J, Bernstein L. Psychometric Theory. New York : MacGrow-Hill Higher, INC. 1994.

14. Risal A, Manandhar K, Steiner TJ, Holen A, Koju R, Linde M. Estimating prevalence and burden of major disorders of the brain in Nepal: cultural, geographic, logistic and philosophical issues of methodology. J Headache Pain. 2014;15:51.

15. Manandhar K, Risal A, Steiner TJ, Holen A, Koju R, Linde M. Estimating the prevalence and burden of major disorders of the brain in Nepal: methodology of a nationwide population-based study. J Headache Pain. 2014;15:52.

16. Peters M, Bertolote JM, Houchin C, Kandoura T, Steiner TJ. Translation protocol for hybrid documents. J Headache Pain. 2007;8(Suppl 1):S40-S7.

17. Francis LJ, Lewis CA, Ziebertz HG. The short-form revised Eysenck personality Questionnaire (EPQ-S): A German edition. Social Behavior and Personality. 2006;34(2):197 - 204.

18. Francis LJ, Brown LB, philipchalk R. The development of an abbrevation form the revised Eysenck Presonality Questionnaire (EPQR-A): Its use among students in England, Canada, the U.S.A. and Australia. Pers Individ Dif. 1992;13(4):443 - 9.

19. Aluja A, Gracia O, Gracia LF. A psychometric analysis of the revised Eysenck Personality Questionnaire short scale. Personality and Individual Diferences. 2003;35:449-60.

20. Shepherd M, Devis B, Culppan RH. Psychiatric illness in a general hospital. Acta Psychiatr Scand. 1960;35:518 - 25. 


\section{इपिक्यूआरएस-एन नेपाली प्रश्नावली}

निर्देशन : कृपया प्रत्येक प्रश्नको उत्तर दिनुहोला ।

प्रत्येक प्रश्नको उत्तर तुरुत्त नै दिनुपर्नेछ र उत्तरका लागि लामो समयसम्म विचार गनं आवश्यक छैन । तपाईंको यथासमयको भावना नै प्रत्येक उत्तरले प्रतिविम्बित गर्नुपर्नेछ।

\begin{tabular}{|c|c|c|c|}
\hline 9 & के तपाईंको मन अस्थिर हुन्छ ? & ० हुदैन & १ हुन्छ, \\
\hline २ & कुनै कारणबिना तपाईं कहिल्यै दु:खी हुनु भएको छ ? & ० छ, & 9 छैन \\
\hline ३ & के तपाईं भर्कने खालको व्यक्ति हो ? & $O$ होइन & 9 हो \\
\hline$\gamma$ & के तपाईंको भावनाहरुमा तुरुन्त चोट पर्दछ ? & ० पर्देन & १ पई \\
\hline y & के तपाई प्राय: निराश भएर बस्नुहुन्छ ? & O बस्दिना & १ बस्छु \\
\hline$\xi$ & के तपाई आफूलाई आत्तिने मानिस ठान्नुहुन्छ ? & O ठान्दिन" & १ ठान्छु \\
\hline$\vartheta$ & के तपाई चिन्तित हुनुहुन्छ ? & O हुन्न & $१$ हुन्छु \\
\hline 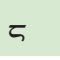 & के तपाई आफूलाई तनावग्रस्त वा अति नै सबल महसुस गर्नुहुन्छ ? & ० गर्दिन" & १ गईु \\
\hline$\rho$ & के तपाई कुनै लज्जास्पद घटना घटेपछि, लामो समयसम्म त्यसैको बारेमा चिन्ता गरिरहनुहुन्छ ? & ० गर्दिन & १ गई्छु \\
\hline 90 & के तपाई आफ्नो चिन्ताबाट दु:खी हुनुहन्छ ? & ० हुन्नं & १हुन्छु \\
\hline 99 & के तपाई प्राय: आफूलाई एक्लो महसुस गर्नुहुन्छ ? & ० गर्दिन" & १ गईु \\
\hline १२ & के तपाई प्राय: आफैले गरेको काम या भनेको कुरादेखि हीनताबोध गर्नुहुन्छ ? & ० गर्दिनाँ & 9 गईु \\
\hline
\end{tabular}

